\title{
A French Teenager's Introduction To International Business Ethics
}

\author{
S. Daly, Lindenwood University, USA \\ Nidhal Djellouli, (MBA student) Lindenwood University, USA
}

\begin{abstract}
This case presents information about a French teenager who wanted to gain experience in an international business company. Several years of working in the international business arena brought experience, expertise, trials, frustrations and valuable career planning tools. Important decisions had to be made - decisions that many employees would not want to handle. Right or wrong, studying the actions of the numerous individuals involved allows readers to gain tools and action plans for dealing with real life business dilemmas.
\end{abstract}

Keywords: Ethics; Case Study; International Business; France

\section{INTRODUCTION}

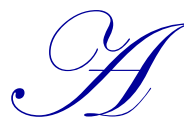

t age fifteen, a young man in France was beginning to learn about tough decisions; or so he thought. He had decided to go study abroad for a year just to experience something new. Lucas had just completed his sophomore year of high school when he began looking on the internet for exchange student programs. After a short time of surfing the internet, Lucas found an organization called La Fleche Verte, or The Green Arrow.

Lucas could not believe how easily he had struck gold! There were a number of organizations that offered him the opportunity to study abroad. However, La Fleche Verte seemed like the complete package as the price included all expenses, such as airfare, insurance, tuition for high school, visa, and other living expenses. The reason he chose this organization over the others was because it was a non-profit organization. Thus, La Fleche Verte would reimburse any money not spent on the student's time studying overseas. According to the company's website, the cost for a year was 8,500 euros to study in the United States.

Lucas decided to tell his best friend, Alexandra, about this program. The affordable price quickly piqued Alexandra's interest. However, she wanted to study six months in Australia and six months in Mexico so the price of her trip would be 14,000 euros according to the website. The teenagers followed up with a phone call to the organization. The person they spoke with at La Fleche Verte further explained the pricing structure by telling Lucas and Alexandra that although they were priced a bit higher than their competitors, they specifically did this so as not to ask the families for more money along the way if the expenses happened to increase. They also assured their customers that they had always been able to return between 200 and 2,000 euros of unused funds. The two friends felt confident they had asked all the questions and received specific answers and were choosing the best company.

\section{FROM CUSTOMER TO EMPLOYEE}

Alexandra and Lucas enjoyed their year abroad. Upon returning to France after a year in foreign high schools, they were offered part-time jobs with La Fleche Verte as local coordinators. According to Caroline Depalma, a local coordinator for exchange students is "responsible for the well-being of the students in their assigned school district. This includes dealing with a student's ability to communicate with teachers and peers, helping new students adjust to a different setting, and making sure that each student maintains a positive attitude" (Depalma). For Lucas and Alexandra, their job was mainly to hold informational meetings and to interview French students who wanted to study abroad. Since their English-speaking skills had improved after their exchange year, 
they were also quickly assigned as coordinators for foreign exchange students who came to study in France. In this role, they also served as the local emergency contact person for the foreign students during their stay in France.

Alexandra and Lucas found themselves gaining increasing experience in international business. They soon became in charge of correspondence with the English speaking families who contacted La Fleche Verte for an array of answers. The two teenagers did everything from answering phone calls to assuring parents their children were safe to answer questions about financing.

After working for La Fleche Verte for a year and a half, Lucas decided he wanted to go to college in the United States directly after high school. The organization he worked for, La Fleche Verte, told him that they were affiliated with an organization called La Pomme Rouge, which means The Red Apple. According to their website, 'La Pomme Rouge is a company specialized in the organization of linguistic and cultural travels abroad'. La Pomme Rouge specialized in finding scholarships for colleges in the United States. Lucas went ahead and submitted his application with this company. He realized that La Pomme Rouge was owned by a lady with the same last name as the owner of La Fleche Verte. When he asked his boss about this coincidence, he told Lucas that they were husband and wife. Lucas was accepted in the La Pomme Rouge program and was awarded a scholarship with a medium-sized university in the United States.

Within a few months, Lucas was flying to the United States and quickly settled into his new university. Soon after he arrived, he met a few other French students. Within the next few days, he met more French students than Americans. At that point, he started asking them how they ended up at this university. They all told him that they went through an organization called La Pomme Rouge - the same company he used. He was shocked and perplexed because they all paid 1,900 euros for La Pomme Rouge program to find them a scholarship, but they all ended up in the same university. Lucas, being skeptical, started asking himself where their money went because the fee was only paid for the service of finding scholarships; the fee quoted by La Pomme Rouge did not include anything else. After a couple of semesters spent at this university, Lucas flew back home for the summer and asked La Fleche Verte for a summer job. He worked there for three months which were the most eventful three months of his short life.

\section{REALIZATION}

Lucas could not quit wondering about the fees he had paid over the years for assistance in finding study abroad opportunities. He had an excellent relationship with his immediate supervisor and one day broached a question. Lucas asked her if La Pomme Rouge was a profit or non-profit organization. She told Lucas they were a profit-based organization and that they were very profitable. Lucas was shocked. He became very curious and used his friendly relationship with his supervisor to get answers to more questions.

One day as he was doing paperwork, he came across a paper that listed all the costs that La Fleche Verte had to pay to send high school students abroad. Discreetly, he calculated the numbers and came up with 6,500 euros. It was a very complete list and included all the costs and fees that applied to him when he went abroad for a year. He asked his supervisor if this was accurate. Was this the real cost of La Fleche Verte service provided to students? If so, how come it was so much lower than the cost in the brochure and on the internet? She told Lucas that they did not spend a dime more than what was on the list but unfortunately was not able to answer the other question. Lucas figured that they must have spent more money on his insurance or his airfare and that it was probably the reason why they only gave him back 250 euros a few years ago when he was part of the program.

A couple of weeks later, La Fleche Verte held an informational meeting for students that were leaving that next school year. A parent came up with her teenager and asked what the cost included and other detailed expense questions. Lucas, recalling the paper he had seen and calculated up, told the parent that it should be approximately 6,500 euros. She seemed happy with his answer and must have repeated this information to someone else in the organization. The next day, Lucas' supervisor's boss came to talk to him. This man was unhappy with Lucas disclosing information he should not know. He told Lucas, who was still a teenager, that this list did not include many expenses and that he could not tell the families anything about company expenses. He did not fire Lucas, but instead asked him if he could replace someone working for La Pomme Rouge and accompany a group of foreign 
college students during a visit of monuments in Paris. Supposedly Lucas would be paid twice as much as his usual salary at La Fleche Verte because La Pomme Rouge was a profit organization and had more funds to pay their workers.

When he received the check for this day of working for La Pomme Rouge, it was from La Fleche Verte and not from La Pomme Rouge. He was a bit concerned so he brought it up to his supervisor. She told Lucas not to worry about it and to go ahead and cash the check. It seemed to the young man that it was something they had done a lot.

The next thing that happened to Lucas during the three summer months was the most disturbing of all. Lucas was struck immediately with the thought that this, above all else, was unethical. He was confused, however. He took time to look up the word and found a definition of unethical as "lacking moral principles; unwilling to adhere to proper rules of conduct, and not in accord with the standards of a profession" (Dictionary.com).

The next informational meeting for parents of future exchange students was approaching. Prior to the meeting, La Fleche Verte, CEO, came to Lucas and told him to withhold information about trip costs and about families getting unspent money reimbursed. More specifically, Lucas was told he could not discuss any subject that involved money and that if he did, he would have to assume serious consequences.

Lucas felt the CEO was being very defensive when it came to this subject and Lucas did not like the fact that he was being threatened. The teenage asked the CEO if he was expecting him to lie. The CEO replied that he was simply expecting Lucas to not disclose the truth by simply not speaking about the topic. To Lucas, it felt like lying.

Lucas immediately began thinking of the time when he was attending those informational meetings as a future exchange student with his parents. He remembered that the people working the event would always avoid questions concerning money. The answer was always the same, that the costs can vary and that they do not know the exact price of the trip until the end of the exchange student year.

Lucas started connecting the dots and realized that La Fleche Verte must always tell families that they are going to get between 200 and 2,000 euros back based on what the costs were, when in reality they only ever give back between 200 and 300. Lucas' parents only received 250 back after his year as an exchange student and Alexandra's parents received 275 euros back after her year in Australia and Mexico.

Lucas figured out that if they did that to all the families, by not spending 2,000 euros and giving back only around 250 euros, they could keep 1750 euros per exchange student. Knowing that they have around 500 exchange students per year, that is 875,000 euros they could make just on this one aspect of the business. Then Lucas considered that he was getting paid by La Fleche Verte instead of La Pomme Rouge for the three replacement jobs he had done. He figured out that La Fleche Verte had to break even at the end of the year because they were a nonprofit organization.

The next thing he realized was that most all the people working for La Pomme Rouge also work for La Fleche Verte. Thus, they could do the same thing with every worker who is working for both organizations. He recalled that the two company owners were husband and wife.

Lucas decided that he would not lie to the families. His decision was based mainly on the fact that he would not want the companies to lie to his family, something they probably had done in the past. The teenager told a few families that the real cost was only 6,500 euros and that they should receive 2,000 back at the end of their child's exchange year.

The families were happy with this answer, but the CEO was not. He came up to Lucas again, this time with a resignation letter and a check. Lucas said that he could sign the resignation letter and enjoy the nice check. What the teenager understood from this situation was that he was getting paid to be quiet. So the teenager asked the CEO why he did not fire him. Lucas even asked the CEO 'if he was scared of something'. The CEO started getting defensive again and told the young man that he could be sued for disclosing confidential information. 
At the time, Lucas was only 19. He was getting his education in the United States and he did not want to be involved in a lawsuit. College was expensive and he would not have been able to afford a lawsuit. He did some research. According to one website, "In rural areas and small towns, lawyers tend to charge less and fees in the range of $\$ 100$ to $\$ 200$ an hour for an experienced attorney are probably the norm. In major metropolitan areas, the norm is probably closer to $\$ 200-\$ 400$ an hour" (Lawyers.com). Lucas had to think of his education first and a lawsuit could have caused him to stay in Paris and miss a semester or two. The expense of hiring lawyers in either country or flying back and forth for court appearances and the mental stress were all factors for Lucas to consider.

\section{UNCOVERED}

A year later, the few families that were told about the real costs of the trip received some money back. They were unhappy to receive between 200 and 300 euros because their mind was set on the fact that they would receive around 2,000 euros. They asked the organization for a detailed summary of all expenses. The organization provided those families with documentation, but there were some questionable expenses that the families had problems with.

For example, on the detailed summary of expenses, it showed informational meeting expenses, transportation to the airport and to school, and many others. The families knew that the price of the trip did not include these items.

The organization stuck to their documentation and found themselves in a lawsuit with several families. The non-French families were completely unaware of this issue. For the most part, they did not know the value of things in France and fully trusted the organization with their money.

One of the French families had connections with the French Ministry of Finance which was made aware of the situation. Consequently, both La Pomme Rouge and La Fleche Verte were audited. The report came back against both organizations and both companies were cited for unethical and illegal actions.

La Fleche Verte, Green Arrow, being non-profit, and La Pomme Rouge, Red Apple, being profit-based were paying for goods and services of La Pomme Rouge with the funds of La Fleche Verte, just as Lucas had known. They were apparently using services that La Pomme Rouge offered to transfer money from La Fleche Verte to La Pomme Rouge, such as transcript translations, guided visits, paying employees from La Pomme Rouge with funds from La Fleche Verte, and many other things. At the end of every month, La Fleche Verte was breaking even, but La Pomme Rouge was very profitable.

The companies were scamming the families and had stayed under the radar of the French Minister of Finance. The main reason the two companies were able to do this for over 20 years was because they were using the money to pay the employees very well, making both organizations a very attractive place to work.

Throughout the years, the owners did not get 'too' greedy and stayed under the radar because they were taking money little by little. They consistently showed expenses with La Fleche Verte that made them break even at the end of the month. Thus, La Fleche Verte continued to receive funding from the French government as a nonprofit. On La Pomme Rouge side, their high profit was used to pay very nice salaries to their employees and the salary that went to the owner made it seem like the business was successful, but not overly so.

\section{CONCLUSION}

At the moment, both owners - the husband and wife - are being tried in court. Many more families have joined the court battle due to word-of-mouth and media coverage. They have a big chance of being charged for larceny which is defined as "typically a non-violent theft involving the wrongful taking and carrying away of someone else's personal property" (free advice). Families associated with the two companies hope they may receive some money back or that others will simply be better protected from this form of theft. 
As for Lucas, he felt obligated to resign and did accept a resignation check. He avoided a lawsuit and felt he was able to act ethically against an organization that was unethical until the end. The teenager felt very bad for the families, many of whom struggled and saved up their whole life to be able to send their kids abroad. Lucas feels very happy for his parents because they worked hard to help him and maybe they could get 2,000 euros back. The teenager hopes the judge decides that the organization needs to give back to every family all their unspent money.

Lucas thinks that as society becomes more focused on consumption and money, such situations will increase. He decided to become a business major based on his early positive experience as an employee and later as a wronged consumer. When it comes to taking advantage of other people, Lucas has strong opinions. He believes that the biggest benefit he got from being caught in this situation was the fact that he realized what his values were.

\section{AUTHOR INFORMATION}

Dr. S. Daly is an Assistant Professor of Business at Lindenwood University in St. Charles, Missouri. Dr. Daly has worked and lived in several Eastern European countries, was awarded an AACSB fellowship, and spent almost a decade in the aerospace industry. E-mail: sdaly@lindenwood.edu (Corresponding author)

Nidhal Djellouli is an MBA student at Lindenwood University in St. Charles, Missouri. Mr. Djellouli received part of his education in Paris, France and part in the U.S. He has over five years of professional and internship experience in both France and the U.S.

\section{REFERENCES}

1. Crane, Thomas. "Employment Law Blog: Employment Lawyer \& Attorney: Thomas Crane Law Firm: South Texas, Bexar County TX Wage \& Discrimination Issues." Length and Cost of a Lawsuit. n.d. Web. 02 May 2012.

2. Depalma, Caroline. "Student Services Coordinator Job Description." EHow. Demand Media, 02 Feb. 2010. Web. 01 May 2012.

3. "Unethical Definition." Dictionary.com. Web. 01 May 2012.

4. "What Is Larceny?" Criminal-law. Web. 02 May 2012. 


\section{QUESTIONS FOR DISCUSSION}

1. What were the main ethical dilemmas in this case?

2. What options could Lucas have pursued?

3. How could the two organizations have avoided all of this mess and garnered the profits they sought?

4. What is your opinion on the decisions that have been taken by both sides?

5. What do you think the two organizations and their owners should be charged for?

6. Would you have lied to the families to make more money if you were in Lucas' shoes? 